\title{
DOSIS NPK DAN KONSENTRASI ZAT PENGATUR TUMBUH TIDAK MEMPENGARUHI PERTUMBUHAN TANAMAN SAWI (Brassica juncea L.)
}

\author{
Muhammad Muaz Munauwar ${ }^{1}$, Sri Jaya ${ }^{2}$
}

Email Author: muhammadmuazmunauwar@gmail.com

\begin{abstract}
ABSTRAK
Tujuan penelitian ini adalah untuk mengetahui dosis pupuk NPK dan konsentrasi Zat Pengatur Tumbuh Atonik yang tepat untuk pertumbuhan dan produksi sawi (Brassica juncea $\mathrm{L}$ ) yang baik, serta interaksi kedua faktor tersebut. Penelitian ini dilaksanakan di Desa Batumbulan Asli Kecamatan Babussalam Kabupaten Aceh Tenggara, dengan ketinggian tempat $\pm 220 \mathrm{~m}$ di atas permukaan laut. Dilaksanakan pada Bulan Desember 2016 s/d Januari 2017. Menggunakan Rancangan Acak Kelompok (RAK) Faktorial, yang terdiri dari 2 (dua) faktor yaitu Faktor pertama yakni dosis pupuk NPK (N) yang terdiri dari 3 taraf yaitu $\mathrm{N} 1=0,50$ gr/plot, $\mathrm{N} 2=1 \mathrm{gr} / \mathrm{plot}$ dan $\mathrm{N} 3=1,5 \mathrm{gr} / \mathrm{plot}$. Faktor kedua adalah konsentrasi Zat Pengatur Tumbuh Atonik (A) yang terdiri atas 3 taraf yaitu A1 = $0,50 \mathrm{cc} / \mathrm{L}$ air, $\mathrm{A} 2=1 \mathrm{cc} / \mathrm{L}$ air dan $\mathrm{A} 3=1,5 \mathrm{cc} / \mathrm{L}$ air. Parameter yang diamati tinggi tanaman, jumlah daun dan luas daun. Hasil penelitian menunjukkan bahwa pemberian pupuk NPK tidak berpengaruh nyata terhadap pertumbuhan, namun ada kecendrungan dimana pemberian pupuk NPK dan ZPT dapat meningkatkan pertumbuhan tanaman sawi.
\end{abstract}

Kata kunci : NPK, Zat Pengatur Tumbuh, Sawi dan Pertumbuhannya

\begin{abstract}
The purpose of this research is to observe the dosage of natrium, phospor and kalium fertilizer and the concentration of Atonic Growth Regulators appropriate for the growth and production of mustard greens (Brassica juncea, L) is good, and interaction of both factors. This research was conducted in Batumbulan Asli Village, Babussalam Subdistrict, Southeast Aceh Regency with its height $\pm 220 \mathrm{~m}$ above sea. This research done in December 2016-January 2017, using Random Block Design (RBD) Factorial, which consists of 2 (two) factors. The first factor is the dosage of fertilizer (N) consisting of 3 levels, $\mathrm{N} 1=0.50 \mathrm{gr} / \mathrm{plot}, \mathrm{N} 2=1 \mathrm{gr} / \mathrm{plot}$ and N3 $=1.5 \mathrm{gr} /$ plot. The second factor is the concentration of Atonic Growth Atonic Growth Regulator (A) consisting of 3 levels, A1 $=0.50 \mathrm{cc} / 1$ water, $\mathrm{A} 2=1 \mathrm{cc} / 1$ water and $\mathrm{A} 3=1.5 \mathrm{cc} / 1$ water. Parameters observed were plant height, number of leaves and leaf area. The results reported that fertilizers did not significantly affect the growth, but there was a tendency where the fertilizers and growth regulator fertilizer could increase the growth of mustard plant.
\end{abstract}

Keywords: fertilizer, growth regulators, mustard and its growth

\section{PENDAHULUAN}

Sawi (Brassica juncea L) merupakan salah satu komoditas tanaman hortikultura dari jenis sayuran yang dimanfaatkan daunnya yang masih muda, sebagai makanan sayuran dan memiliki macam-macam manfaat serta kegunaan. Dalam kehidupan masyarakat sehari-hari sawi selain dimanfaatkan sebagai bahan makanan, sayuran juga

\footnotetext{
${ }^{1}$ Program Studi Agroekoteknologi Fakultas Pertanian Universitas Malikussaleh, Aceh Utara

${ }^{2}$ Universitas Gunung Leuser, Aceh Tenggara
} 
dapat dimanfaatkan untuk pengobatan (Cahyono, 2003).

Menurut Barbarick (2006), pemberian pupuk NPK pengaruhnya sangat besar terhadap pertumbuhan dan produksi tanaman sawi. Nursanti (2009) melaporkan hasil penelitiannya bahwa pemberian pupuk NPK menyebabkan tanaman sawi tumbuh dengan baik ditandai dengan tanaman yang tinggi, daunnya banyak dan tanamannya berat.

Penggunaan pupuk NPK dapat menjadi solusi dan alternatif dalam meningkatkan pertumbuhan tanaman sawi. Penggunaan pupuk NPK diharapkan dapat memberikan kemudahan dalam pengaplikasian di lapangan dan dapat meningkatkan kandungan unsur hara yang dibutuhkan di dalam tanah serta dapat dimanfaatkan langsung oleh tanaman (Lestari, 2011).

\section{Penggunaan Zat Pengatur} Tumbuh untuk meningkatkan pertumbuhan dan produksi tanaman sayuran. Zat pengatur tumbuhan tanaman adalah senyawa organik bukan hara tanaman yang aktif dalam jumlah kecil yang disintesa pada bagian tertentu dari tanaman dan pada umumnya diangkut pada bagian lain dari tanaman, dimana zat pengatur tumbuh tersebut menimbulkan respon secara biokimia, fisiologis dan morfologis. Zat Pengatur Tumbuh Atonik merupakan pupuk daun lengkap yang mengandung unsur hara makro dan mikro, sehingga dapat menyuburkan dan melipat gandakan pertumbuhan dan hasil semua jenis tanaman (Sunarjono, 2003).

Hingga saat ini belum diketahui dosis pupuk NPK dan konsentrasi Zat Pengatur Tumbuh (ZPT) yang tepat untuk meningkatkan pertumbuhan dan produksi sawi, sehingga perlu dilakukan suatu penelitian agar dapat ditemukan dosis dan konsentrasi yang tepat.

\section{Tujuan penelitian}

Tujuan penelitian ini adalah untuk mengetahui dosis pupuk NPK dan konsentrasi Zat Pengatur Tumbuh yang tepat untuk pertumbuhan sawi (Brassica juncea, L).

\section{Hipotesis}

1. Dosis pupuk NPK berpengaruh terhadap pertumbuhan dan produksi tanaman sawi.

2. Konsentrasi Zat Pengatur Tumbuh berpengaruh terhadap pertumbuhan dan produksi tanaman sawi

\section{BAHAN DAN METODA PENELITIAN}

\section{Tempat dan waktu penelitian}

Penelitian ini dilaksanakan di Desa Batumbulan Asli Kecamatan Babussalam Kabupaten Aceh Tenggara, dengan ketinggian tempat $\pm 220 \mathrm{~m}$ di atas permukaan laut. Penelitian ini dilaksanakan pada Bulan Desember 2016 s/d Januari 2016.

\section{Bahan dan alat penelitian}

Bahan yang digunakan dalam penelitian ini adalah benih sawi, pupuk NPK, zat pengatur tumbuh Atonik, Insektisida, Decis 50 EC, pupuk NPK, sedangkan alat yang digunakan dalam penelitian ini adalah cangkul, garu, meteran, bambu, kayu plat, gembor, timbangan, handsprayer, tali dan alat tulis lainnya.

\section{Metode penelitian}

Penelitian ini menggunakan Rancangan Acak Kelompok (RAK) Faktorial, yang terdiri dari 2 (dua) factor.

Faktor pertama dosis pupuk NPK (N) yang terdiri dari 3 taraf yaitu: 
$\mathrm{N} 1=0,50 \mathrm{gr} / \mathrm{plot}$

$\mathrm{N} 2=1 \mathrm{gr} / \mathrm{plot}$

$\mathrm{N} 3=1,5 \mathrm{gr} / \mathrm{plot}$

Faktor kedua adalah konsentrasi ZPT Atonik (A) yang terdiri atas 3 taraf yaitu:

$$
\begin{array}{ll}
\text { A1 } & =0,50 \mathrm{cc} / \mathrm{L} \text { air } \\
\text { A2 } & =1 \mathrm{cc} / \mathrm{L} \text { air } \\
\text { A3 } & =1,5 \mathrm{cc} / \mathrm{L} \text { air }
\end{array}
$$

Sehingga diperoleh kombinasi perlakuan sebagai berikut:

$\begin{array}{lll}\text { N1A1 } & \text { N1A2 } & \text { N1A3 } \\ \text { N2A1 } & \text { N2A2 } & \text { N2A3 } \\ \text { N3A1 } & \text { N3A2 } & \text { N3A3 }\end{array}$

Jumlah ulangan (blok)

$$
=3 \mathrm{kali}
$$

Jumlah plot

$$
=3 \times 9=27 \text { unit }
$$

Jumlah Tanaman/Lubang Tanam

$$
=1 \text { Tanaman }
$$

Jumlah Tanaman/Plot

$$
=25 \text { Tanaman }
$$

Jumlah sampel per plot

$$
=5 \text { Tanaman }
$$

Jumlah tanaman seluruhnya

$$
=675 \text { Tanaman }
$$

Jumlah tanaman sampel

$$
=135 \text { Tanaman }
$$

Jarak tanam

Luas plot

$$
=30 \times 30 \mathrm{~cm}
$$

Jarak antar plot

$$
=150 \mathrm{Cm} \times 150 \mathrm{~cm}
$$

$$
=50 \mathrm{~cm}
$$

Jarak antar blok

$$
=50 \mathrm{~cm}
$$

\section{Paramater yang diamati}

Parameter yang diamati adalah tinggi tanaman, jumlah daun, luas daun.

\section{HASIL}

\section{Tinggi tanaman}

Data penelitian pengaruh dosis pupuk NPK dan kosentrasi zat pengatur tumbuh terhadap tinggi tanaman sawi umur 5 minggu setelah pindah bibit disajikan pada Tabel 1. Dapat dilihat bahwa pemberian dosis pupuk NPK dan kosentrasi Zat Pengatur Tumbuh berpengaruh tidak nyata terhadap tinggi tanaman.

Table 1. Tinggi tanaman sawi umur 5 minggu setelah pindah bibit $(\mathrm{cm})$

\begin{tabular}{|l|l|l|l|l|}
\hline Perlakuan & A1 & A2 & A3 & $\begin{array}{l}\text { Rata- } \\
\text { Rata }\end{array}$ \\
\hline N1 & 19,92 & 24,99 & 21,91 & $22,27 \mathrm{a}$ \\
\hline N2 & 25,30 & 23,67 & 21,51 & $23,49 \mathrm{a}$ \\
\hline N3 & 19,13 & 22,19 & 25,34 & $22,22 \mathrm{a}$ \\
\hline Rata-Rata & $21,45 \mathrm{a}$ & $23,62 \mathrm{a}$ & $22,92 \mathrm{a}$ & 22,26 \\
\hline
\end{tabular}

Keterangan : Angka-angka pada masing-masing kolom diikuti huruf kecil yang sama berbeda tidak nyata menurut UBD pada taraf nyata $5 \%$

\section{Jumlah daun}

Pada Tabel 2 dapat dilihat data penelitian pengaruh dosis pupuk NPK dan kosentrasi zat pengatur tumbuh terhadap jumlah daun tanaman sawi umur 5 minggu setelah pindah bibit. Pemberian dosis pupuk NPK dan kosentrasi Zat Pengatur Tumbuh tidak berpengaruh nyata terhadap jumlah daun.

Tabel 2. Jumlah daun tanaman sawi umur 5 minggu setelah pindah bibit (helai)

\begin{tabular}{|l|l|l|l|l|}
\hline Perlakuan & A1 & A2 & A3 & $\begin{array}{l}\text { Rata- } \\
\text { Rata }\end{array}$ \\
\hline N1 & 6,33 & 7,93 & 7,40 & $7,22 \mathrm{a}$ \\
\hline N2 & 7,87 & 7,93 & 6,37 & $7,39 a$ \\
\hline N3 & 6,40 & 7,07 & 7,67 & $7,05 a$ \\
\hline Rata-Rata & $6,87 a$ & $7,64 a$ & $7,15 a$ & 7,22 \\
\hline
\end{tabular}

Keterangan : Angka-angka pada masing-masing kolom diikuti huruf kecil yang sama berbeda tidak nyata menurut UBD pada taraf nyata $5 \%$ 


\section{Luas Daun}

Pengaruh dosis pupuk NPK dan kosentrasi zat pengatur tumbuh terhadap Luas daun tanaman sawi umur 5 minggu setelah pindah bibit dapat dilihat pada Tabel 3. Pemberian dosis pupuk NPK dan kosentrasi Zat Pengatur Tumbuh tidak berpengaruh nyata terhadap luas daun.

Tabel 3. Luas daun tanaman sawi umur 5 minggu setelah pindah bibit $\left(\mathrm{cm}^{2}\right)$

\begin{tabular}{|l|l|l|l|l|}
\hline Perlakuan & A1 & A2 & A3 & $\begin{array}{l}\text { Rata- } \\
\text { Rata }\end{array}$ \\
\hline N1 & 94,08 & 152,70 & 121,44 & $122,74 a$ \\
\hline N2 & 132,57 & 131,85 & 113,85 & $126,09 a$ \\
\hline N3 & 98,49 & 110,05 & 127,15 & $111,90 a$ \\
\hline Rata-Rata & $108,38 \mathrm{a}$ & $131,53 a$ & $120,81 \mathrm{a}$ & 120,24 \\
\hline
\end{tabular}

Keterangan : Angka-angka pada masing-masing kolom diikuti huruf kecil yang sama berbeda tidak nyata menurut UBD pada taraf nyata $5 \%$

\section{PEMBAHASAN}

Pemberian pupuk NPK dan konsentrasi ZPT tidak berpengaruh nyata terhadap tinggi tanaman, jumlah daun dan luas daun. Hal ini diduga terjadi akibat nilai antara satu taraf perlakuan dengan taraf perlakuan lain tidak terlalu besar perbedaan nilainya (tidak ekstrim).

Walaupun hasilnya menunjukkan perbedaan tidak nyata, namun dari Tabel 1, Tabel 2 dan Tabel 3 terlihat kecendrungan semakin besar dosis pemberian pupuk NPK dan konsentrasi ZPT maka semakin besar nilai tinggi tanaman, jumlah daun dan luas daun. Nilai pertumbuhan yang cenderung meningkat diduga karena pupuk NPK mampu memperbaiki struktur tanah, menyuburkan tanah dan menambah tingkat kesuburan tanah sehingga pertumbuhan tanaman dapat meningkat. Menurut Ryan (2010) semakin besar unsur hara tersedia akan mengakibatkan pertumbuhan tanaman berlangsung lebih cepat. Kecendrungan peningkatan nilai pertumbuhan juga terjadi pada pemberian ZPT, karena ZPT merupakan Zat yang dapat mempercepat pembelahan, pemanjangan dan pembesaran sel (Erita, 2010).

\section{KESIMPULAN DAN SARAN}

\section{Kesimpulan}

Pemberian Dosis pupuk NPK dan konsentrasi ZPT yang berbeda tidak berpengaruh terhadap pertumbuhan tanaman sawi.

\section{Saran}

Perlu dilakukan penelitian lanjutan pemberian pupuk NPK dan konsentrasi ZPT dengan perbedaan nilai yang besar lagi (ekstrim) antara satu taraf perlakuan dengan taraf perlakuan lain.

\section{DAFTAR PUSTAKA}

Barbarick K. A. 2006. Nitrogen Sources and Transformations. Colorado State University. U.S. Department of Agriculture and Colorado counties cooperating

Cahyono, 2003. Budidaya dan Analisis Tani. Kanisius. Jakarta

Erita Hayati, 2010.Pengaruh Pupuk Organik dan Anorganik Terhadap Kandungan Logam Berat Dalam Tanah dan Jaringan tanaman Selada. Jurusan Agroteknologi, Fakultas Pertanian, Universitas Syiah Kuala, Banda Aceh. 
Lestari, L. B. 2011.Kajian Zat Pengatur Tumbuh Atonik Dalam Berbagai Konsentrasi dan Interval Penyemprotan Terhadap Produktifitas Tanaman Bawang Merah (Allium ascollanicum L.). Fakultas Pertanian Universitas Mochamad Sroedji Jember.

Nursanti D.F., 2009 Pengaruh Pemberian Pupuk Organik Terhadap Pertumbuhan dan Hasil Tanaman Sawi Caisim. AgronobiS, Vol. 1, No. 1: 89-98.
Ryan, Ishak (2010), Respon Tanaman Sawi (Brasica juncea L.) Akibat Pemberian Pupuk NPK dan Penambahan Bokashi pada Tanah Asal Bumi Wonorejo Nabire. Fakultas Pertanian Universitas Satya Wiyata Mandala - Nabire.

Sunarjono H., 2003. Bertanam 30 Jenis Tanaman Sayur. Jakarta: Penebar Swadaya 